\title{
SPACE ORIENTED APPROACH IN TRAINING ARCHITECTURAL DESIGN
}

\author{
Alireza Ghayourfar \\ Ph.D. Student in Architecture, Art and Architecture Collage, Islamic Azad University, Science and \\ Research Branch, Tehran, Iran \\ alireza.ghayoorfar@gmail.com \\ Iraj Etesam \\ Professor in Architecture, Art and Architecture Collage, Islamic Azad University, Science and \\ Research Branch, Tehran, Iran \\ ietessam@hotmail.com \\ Seyed Mostafa Mokhtabad \\ Professor in Architecture, Art and Architecture Collage, Islamic Azad University, Science and \\ Research Branch, Tehran, Iran
}

\begin{abstract}
Architecture Art improving the human space He lived in the fullness of time. Recognizing the need of every human being and his own existence. This recognition space in the fullness of their permanent and environment is formed. Texture of geometric order, body space Permanent full-time in the objective-subjective paradigm becomes fixed, but always subject to criticism. Review this harmonious interlacing method not only realized later body the space but also the biological aspect of human evolution led to the creation space The architectural essence of architecture education; space, subjective visualization is not enough. Current trends in innovation in architectural education according to subjective body, areas of biological review space independent narrowed because of conception space than being space human and creative role in creating location-dependent variable in the assessment of the measure space Put to the test by coach research paper analysis, coding method creates a conceptual model and interpret data in order to confirm that it benefited. The results indicate the existence of the interrelationship between the environment and people's sense of identity derived from sense perception as the highest grade space.
\end{abstract}

Keywords: $\quad$ Space, body space, biological space perception, architectural training approach, evaluation criterions space.

\section{EĞİTIM MIMMARİ TASARIMDA UZAY ODAKLI YAKLAȘIM}

ÖZ

Mimarlık; her insanın kendi varlığını tanımasına yardımcı olmaktadır. Geometrik düzenin Doku, nesnel-öznel paradigma vücut alanı kalıcı tam zamanlı sabit ama eleştiriye her zaman maruz kalır. Ancak daha sonra vücuda oluşturma alanı mimarlık eğitiminin mimari özü yol alan değil, aynı zamanda insan evriminin biyolojik yönünü bir araya geçmesiyle gözden geçirilmesidir. Kodlama yöntemi bir kavramsal model oluşturur ve bu fayda olduğunu teyit etmek için verileri yorumlanmaktadır. Sonuçlar çevre ve yüksek dereceli alanı olarak duyu algı türetilen kimlik insanların duygusu arasındaki ilişkinin varlı̆̆ına işaret etmektedir.

Anahtar Kelimeler: Uzay, vücut alanı, biyolojik uzay algısı, mimari eğitim yaklaşımı, değerlendirme kriterleri alanı.

\section{INTRODUCTION}

Copyright (C) The Turkish Online Journal of Design, Art and Communication 
In the field of architectural education, the need for a consistent approach in the way courses are taught by professors of architectural design, the need to limit the selection of students and review architectural education period has been debated, but the emphasis on providing appropriate teaching methods architecture in order to achieve the objectives in accordance with the value that, far from being one-dimensional and detailed criteria to judge architecture; it has no value or called. In assessing the architecture, primarily basic criteria in assessing the substance of architecture, «space» and the perceived overall it has been neglected. The definition of space in architecture has two aspects: body and life in these two categories, the theoretical framework of this paper is formed.

Means a place of human events and things that happened in the space of different situations will determine more than anything means that event without reference to a place, time, and biological behavior of people in that situation think us nothing more than an abstract situation. So where are immensely qualitative, cannot be connected to any of its components, such as body; Biological time, space relations spending without integrated nature of the consideration to be reduced. Friendly relationship with the world and his presence in space requires the relationship of man's environment. The concept of living space, is the voice of human presence in space, that space must listen to understand the meaning (Schultz, 2002, 61,).

In recognition of the fact that architectural space. Space that is as tangible as talk the talk about the environment and time, without having to provide a reason for it. At the same time the perception of human life, time passes; existence at the same time. As about its existence and do not have to give reasons, to define the space we do not feel the need to appeal to their reason. Both the attitude of positivism and formalism to the body to space and we realize the value of life are neglected space (Falamaki, 2011, 1-11).

Social impact assessment requires a judgment on the effectiveness and desirability of the product, process, or program in terms of objectives and values listed together in time. Finally, space meets the physical and psychological needs of man according to the accepted values, the time is (Mirriyahi, 2006, 88).

Diversity and human values and transforms them in time, because none of them is erroneous, the story of man's inability to understand the extent of the issue and their relationship. Operation assessment is a weighted value and tries to convince and mobilize together in a group experience, the group agreed to inter subjectivity and humans (Raeis Dana, 1991; quoted by john P. Qiuz, 1992, 96-130).

In view of existentialism 2 to understand phenomena such as cognitive aspects of life in space is focused on understanding of temporality. Words temporal perception 3, a description that describes cognition as Husserl, Heidegger versus 4 in perception and weight effects, which also include architecture is used by us to the importance of the historicity of understanding and thought lived in dealing with architectural object is called. In the book "Being and Time" Heidegger 5 emphasize that Descartes 6 from the perspective of analogy and deduction, induction and Kant, David Hume 7 of 8 with subjectivism trying to understanding the phenomenon; participants, but and "subjective" see Grand (Partoei, 2008, 65-87).

The word "living" Norberg-Schultz or "living world" Martin Heidegger's phenomenological human presence in and understanding of each event but an ongoing perceptual interaction (internal) and objective (external) point reduction in the speech to renounce Schultz Place interpreted components.

The perception and evaluation criteria for space to apply the approaches of "reason" and "sense" in view of epistemology 9 Divided, in effect the outside, so to speak the object to the subject from the perspective of ontology 10 are led to the perception and the sense of space in polar biological process at the same time, understanding and simultaneously increase the sense of human presence on the space resulting from the (Heidegger, 78, 2007). 
Heidegger considered the polarized space-time location containing biological characteristics. Space that will meet the specific characteristics of a human being, he is the biological evolution perception of the event in terms of biological, against subjectivism refers to national.

In fact, our understanding of space-time, the result is the same match and mind. "world of space» all efforts of the architect in order in terms of geometry, to the emergence of space as the essence of architecture. Architecture as a reality that is crystallized in space can be devoid of many human values - civil and away from the depth of human culture, only needs to be mechanical (Falamaki, 2011:2).

In the definition and implementation of the architecture - an architecture student teacher in the knowledge space, which lies to achieve their common criteria in the categories of "perception of space», «creation - innovation" and "value space» has been discussed.

\section{THE CONCEPT OF SPACE FROM DIFFERENT PERSPECTIVES}

Human understanding of space should be considered in the process and objective interpretation to existential and ontological interpretation in relation to the environment and the time he placed carefully and markets. The initial impression of the category space, not format, as human perception of body is space, object space, what is more external than internal. Then, in the inner perception becomes something that is not a matter of personal judgment and personal attitude. But in later life, ontologically on internal communication - meets the identity and recognition of human existence in the external environment is emphasized; look what Ralph Edmund biological means out of the body at the same space with biological behavior of human beings in space. In fact, each one subject to another Schultz and Heidegger's phenomenological the last opinion on this aspect has been built. In recognition of this trend, consider garlic defined space.

In the material, space as the negation of the mineral, and wide aperture, size and location that is occupied by matter, has been interpreted (Moein, 1976).

Wherever there's space experience, displaying introducing body just is not enough space, the space is full of people. (Zuy, 2009, 66)

Transparency in the definition of the meaning of space should be pointed out that the meaning of the space of the "attenuation" and "Gods" (mind) in "Earth" and "heaven" (the same) will appear (Heidegger, 2007, 40).

The literal definition of language and words change over time and space in which different interpretations and aspects of different fields of physics, geometry, and mathematics to social, cultural and psychological environment in the covers.

The Greek word for «space» did not exist and instead the term "between" was used. Greek philosophers into space, "object reflects," they said. Plato, Lucretius with the help of vision "geometry" to "the science of al-space» called. This distinction body in the circle conceptual aesthetics of the theory of space 12 (maul) Aristotle's theories of space has continued to Euclidean geometry. In the renaissance, Newton's concept of absolute space and time and three-dimensional body that it fills, defined and Giordano Bruno of surrounding space and the space between being enclosed in violation of "space component larger space" Aristotle raised. With the advent of three-dimensional space that functional vision of the Renaissance linear perspective, the distinction between the human consciousness and what perceives tangible circle, opened the way for the separation of the objective and subjective space. Proposed by Descartes in the seventeenth century metaphysical space, yet are physics and Cartesian coordinates will pave the way for understanding the physical space? Before Descartes, space was only qualitative characteristics. Space Leibniz relative to the relationship between components in space and "symbiotic system objects," or military time, was formed. According to Newton space and time real objects and container with unlimited expansion and stationary and moving objects is not related to other components, while system recall 13 Leibniz and the Heisenberg uncertainty principle, space continuous, elastic, imagine the effect of components. What Einstein it "space Jelly" (Wikipedia sing., 2013) 


\section{- ENVIRONMENT - SPACE}

The coexistence of space - time and close relationship resulting from human life, body attitude of the space or the time to get it, as it reflects the substance or the mere negation mineral called, was abolished. Contemporary philosopher, Hegel did not believe in the truth of space and time. In Hegel space - time is just an illusion of our inability to see the whole. Space cutout characterized as a matter of fact arises that, while time, "homogeneous accumulation of moments," the main characteristics of life is affected by components In fact, the only effective and mathematical time, is a form of space (Bergson, 1997, 53).

Attitude to space as they give a range and horizon, and graceful pause is the beginning, the concept of space as a space instead of objects, which is considered as a container material body is taken away, and then existential, biological, and ontological space is close. The involvement and continuity perception of matter and space; space relationship with nature can be seen as material interactions. What is it like to actually be interpreted as an understanding of the interaction of matter and space and its impact on human perception begins. In this view, nothing more than an opportunity temporal space (bio) is not material to occur. The rhythm of life is the perception of space (Schultz, 2001, 7).

Biological tissue is actively passive space. By moving the three-dimensional texture, space for active and passive on both affect positively the matter. Because the sentence geometry and mathematics, space main positive negative sequence of geometric volumes creating the biological life of the city is interpreted. Polar disorder by certain biological elements. Space is always dependent on the observer's location. The term «space» on the basis of the content suggests. In most schools of thought in contemporary architecture, space is three-dimensional spatial transformation that has been polarized and connotation.

City surrounded by walls, is reminiscent of the universe. Finally, a symbolic place where heaven and earth to the origin of the universe of reason leads (Ardalan and Bakhtiar, 2002, 48).

Attachment and need humans to space rooted in the biological situation and his need to be linked. Space for a range of life-time and situations. Space represents a special kind of relationship, but also a platform for communication is (pronoun, 2011, 51). Space is seen as something abstract, geometric, abstract and categorical little scientific evidence on the horns of mechanical relationships, and certain scientific and human nature being as he is in violation of eligible possession. World of alternative models and the first tangible contact us. The modern definition of the characteristics and color space for alternative living space is an empty element (beam, 2008, 65-87). Scientific approach and the first tangible proof of human contact with the space environment and space to discard the historicity of understanding, man is trapped in a world of abstraction (Heidegger, 2007, 22). Space defined in different ways, but there are also differences in the extent of overlapping space have been certain markets. In physics, space "space of absolute", "space Euclidean", "space of gel," in Psychology location, "space of mind", "space theoretical" and in the perception of the "space of targeted communication», «space of inner », « space of output "and hierarchical sense of place, and behavioral bases" The working space "and « space of perception "and divided. Architecture and visual arts space in the area is expansive and pervasive yet in a position to define the physical dimensions or the mind and with the attributes of "empty" or "full" is measurable (Golabchi and Alaghemandan, 2010, 19 22).

polymorphic space 14 in its initial definition is the essence of the unique character trait that some people have attributed to the character and unique property, certain colors are polarized, meaning that in the course of a process of perception of the objectives the knowledge of nature, constitute an 'sense location. "Check this space character in space become the "place" on the basis of phenomenological perspective proves that place, a set of symbols to represent the elements of the environment that is based on the characteristics of existentialism. Based on an awareness and understanding of the nature and space to space centers and in-depth content from being introduced into the human 
existence. Understanding space, unchanging, fixed contract, but to the audience, space at the time of his biological evolution depends. (Relph, 1976, 68).

Ideas that belong to a particular social group time, the reproduction of social life in terms of space time special memories in the form of characteristic paradigm of "identity" paradigm. These are nothing more than a mere body model (Boyer, 1998, 167).

Finally, the evolution of the definition of "space" according to different views, in Figure 1 is summarized.

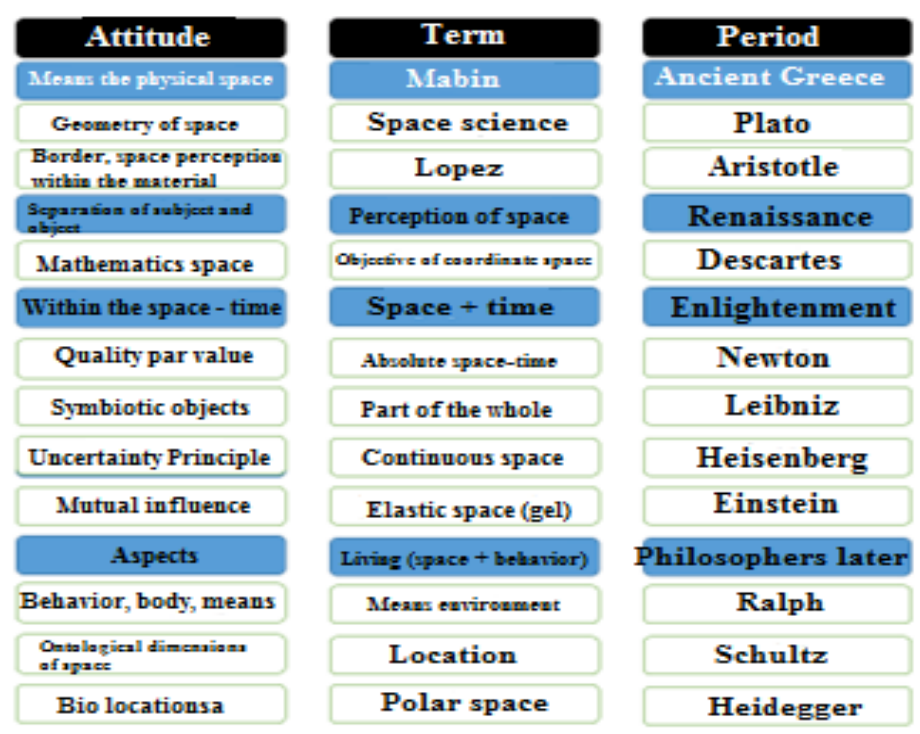

Figure 1. The full definition of literal space during different periods

\section{-FIGURE TO SPACE EDUCATION IN THE FIELD OF ARCHITECTURE}

Architecture as a dynamic art that never stops pattern or style has not, during the life of man has been forced to train. In the past, the process of learning the oral environment was done with the creation of more pragmatic and empirical learning process, relied more on the development of architecture in the modern era with the common thinking specialization in the special sciences and Industry, as a wise architect's comprehensive environmental sciences who have been apart from their society, space while creating the biological aspects taught and tested and matched for optimal human life and in the process was modified to become professor and teachings are always subject to modification at the opportunity to teach his life, suddenly become subjective personal, specific, general superiors and most people were friendly, but has the novelty of an elite. The views expressed are not eligible architecture biological and human environment has evolutionary time, criticism of the space defined criteria to assess the space in time through architect, created the role of space in a permanent process of evolution and the creation of rejection and reference John's life was in the way of understanding the universe itself. Interpretation of Heidegger in Being and Time, location, bio city human life in time and space in order to identify the body of a human being interpreted as "biological life of the city" is.

\section{- EVALUATION CRITERIONS}

Architecture as art is always created in the process of human life and 15 are witnessing the decline of the pure and biological paradigms have been and will be. The continuous creation and variable, space by various criteria material and spiritual, human or superhuman is evaluated or measured. The acquired knowledge of the person, resulting from experience gathered by relying on the opinion of a person to the rank of ijtihad 'elite' and intuitive knowledge to evaluate the effect of different kinds of texts sent and rely and trained. Between stability and change, and plural. St. Fundamentalist belief in the proven principles of eternal unchanging with great atmosphere in contrast 
with increased knowledge and personal experience of the person leaning out of ideas of modern humanism each claimant's evaluation of the effect of space, from the window his vision.

In the field of education, in fact, the two methods measure students' creativity and freedom of action and adopt principles remain constant and can be a measure of the educational process (Markus, 2003).

The scrutiny should point out that the assessment requires a judgment on the social effectiveness and desirability of the product, process or application is accepted by the community (Mirriyahi, 2006, 8696) accepted traditional society, high and Evolution environmental and spiritual values accepted modernity, innovation, joy and discovery and personal experience in the form of instability, what the term "fashion" is, is.

The human mind always looks for patterns in time to gradually learn, experience, and refused to be screened. It will be replaced this experience in mind and the successive changes in the (Abercrombie, 1969).

The root cause of changing the evaluation criteria of experienced human space, create space on the diverse and varied at different times must be matched by human standards, mental, psychological and functional aspects, in accordance with the time he was living. In a word, the man is space. Space In accordance with objective criteria and subjective time of his life. Norms and principles of space biological assessment bodycharacteristics space-based mental health and life of people benefiting from space, is a measure of body space on these principles have been established. Body meets the biological approach to mental health been collected. From the perspective of psychology, social benefits in enhancing mental health through a positive impact on beneficiary groups matched (at the time) is a measure space (Abercrombie, 1969). Measure of space in architecture and architectural education of the oral bio-key presence both architect with people benefit from space which is now present in education, to devote space of body or mind realistic image of the space is reduced. (H., 2012, 63)

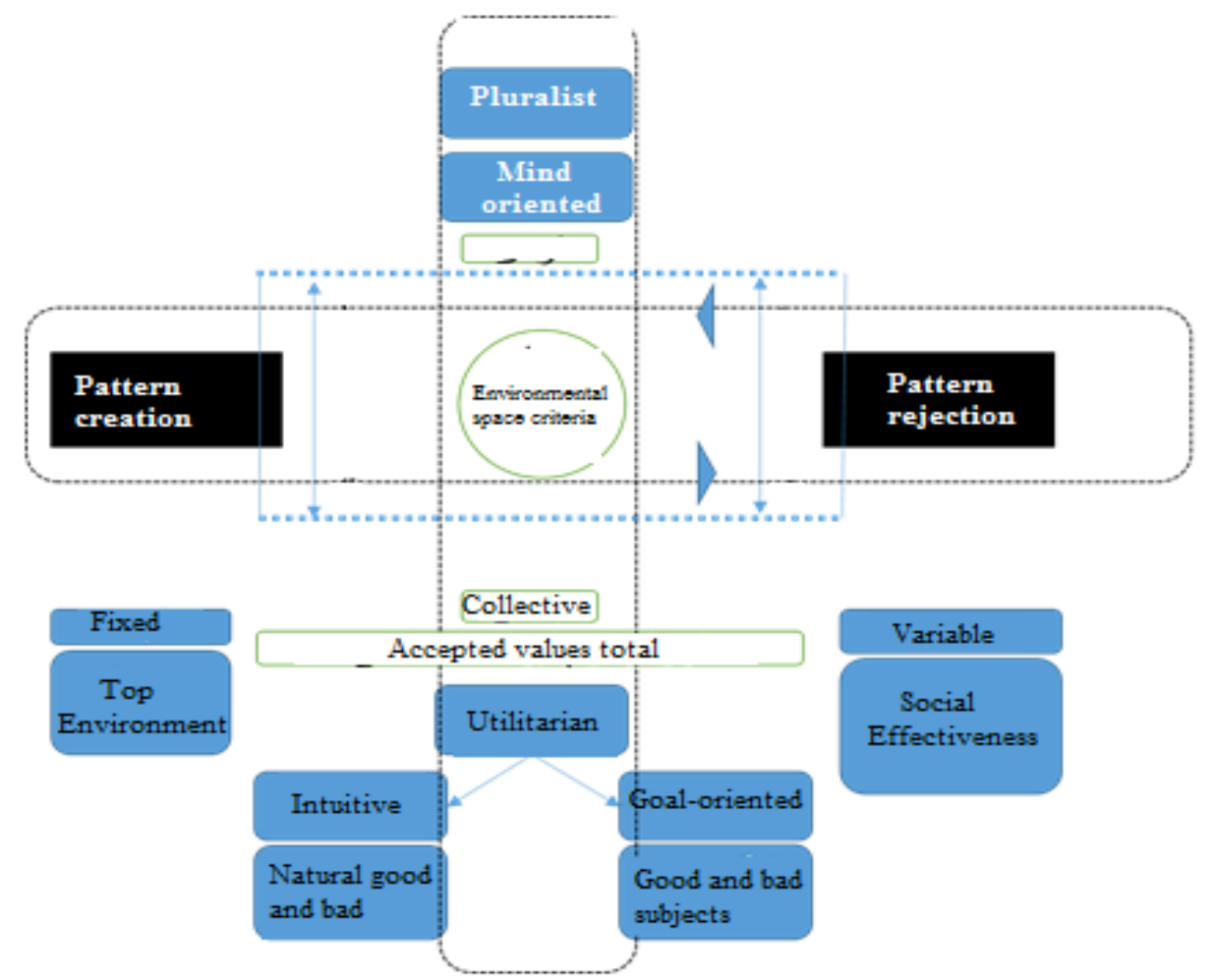

Figure 2 evaluation criterions of thinking

As shown in Figure 2 is based on thoughts (Worthen, 1987) and (Abercrombie, 1969) observed the aim of organizing space of the effect over time of transformation has, as noted goal of social in the 
mental health measure that view Claimed great tradition and the idea of saving the intellectual movements of modernity with joy claim to novelty in the environment causing the separation of boring monotonous life motto personal knowledge and innovation to put the human attributed to patterns of unstable space in closets by individual or collective value can be established. The prevailing criteria in two ways, good and bad, or good and evil innate students meet higher environmental requirements have been introduced. In both schools, the values listed in inter subjectivity consensus was gathered in space- time biological evolution, one with knowledge acquired, the other jurisprudential knowledge-intuitive.

"Long is genuine sympathy Foe»: space for individual colors varies over time. Choose humans from space subjective criteria in accordance with the space - time work lies.

Process design, action-reaction that led to the organization of space. This space of life, man needs in providing assistance. Different needs during the biological evolution of man (Kurt, 2009, 401-408).

Figure 3 represents the course of the transformation of amorphous space of the body or the base color morph of the space or pole to identity and sense of place based on comments made Kurt is high.

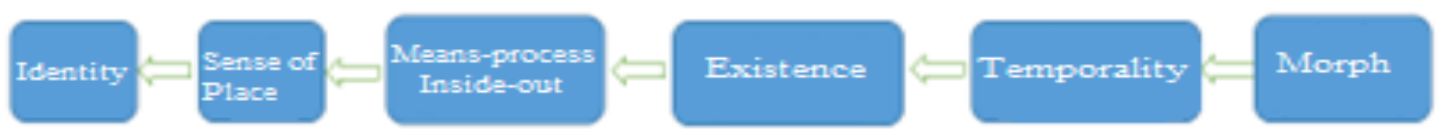

Figure 3. Gradual transformation of space; mineral negate the biological identity (Kurt Sunch model)

Today, education is at a crossroads architectural illumination, innovation, acquisition or referred to the conflict between two attitudes common in our architecture now.

Space on the meaning of human perception, objective image in the mirror of the heart and mind space. A mirror that tells of human identity. Space image obtained the evidence (objective and external) and are between. Iran architecture, space has its own identity with the man; the impact of McCain on location (H., 1998, 19).

Despite the focus on innovation in the schools of thought of modernity with originality against tradition-oriented, despite the sublime in the space from the perspective of ontology is not rejected. However, understanding the meaning of the intellectual space by pure reason is a cognitive degeneration (Akram, 2003, 33).

Even though most learned professors of architecture in contemporary modern school and schools of thought are emerging from it, depending on the tool grip space The pen to the computer and space The spontaneous creation of advanced mathematics without the intervention of the human mind fluctuates, in the course of his education from the space The effect as architect-benefit and environmental exposure with space during its creation space Truly been deprived. However, nearly $80 \%$ of the teachers on the need for student creativity in the learning process of the social productive environment for the mental health of people benefiting from space have emphasized. Of these, the masters of the pen, in the sense of the older professors with mind and his pen and paper and without the help of computers to organize space have, the sublime and eternal principles and promote the creation of the beginning of the design process space Acknowledging have personal knowledge of the principles of environmental elite considered acceptable. Meanwhile, the vast pen and computer teachers, the present system of education, regardless of the ongoing evaluation of biological safety space The creation of knowledge, emphasizing that merely mimic the form and for the most talented students from schools of architecture today body Material works by famous architects, since they understand body space Without review by and only through a few pictures is not possible, let alone understanding the meaning of life lived effect that requires an understanding of the deep layers or a school fascinated; copying of form and color magazines and an eclecticism have journalistic West. Finally, a friendly expression space although the orientation of the individual. So the person says Ralph place as 
Edmund lost half of his identity and many people this century, despite acquisitions space Yi to live, to count homeless people, the human condition placeless place in the current counting. The sense of identity space Rooms, to stand sacrifices to place, country, patriotism and sense of homeland and die in the battle for the place-town word meant and in particular "identity" is based on personal feelings to the argument based on reason " said Shawn "based on the passions 16 and said," Gannon "is based on $17^{\circ}$ mentalism.

\section{- HIGH FRIENDLY}

Meaning beauty in traditional art civilization is that humans understand the world of absolute truth (Nasr, 37, 2000).

\section{GARLIC THEORETICAL FRAMEWORK TO MODEL}

The mental communication objective, living (human space - time) at full rejection and reference (in terms of administration, analysis) to his people that move in space without proper characteristics as a place to pause and stop to call. High environmental and innovation or what is now the term "transient fashion", the two criteria used to evaluate the effects of space architecture is of interest to teachers. Some of the teachers in the teaching of architecture in terms of exact sciences, positivist lived assessment process, and some without regard to biological evolutionary paradigms to evaluate the characteristics of their Actuality, illumination, the novelty of the wave properties of a society and resulting inter subjectivity as a collective and as opposed to a deal with the wave of a society is freedom of choice. The experimental method 18 that a society chooses to unchanging principles tradition of teaching architecture. In order to accept or reject any of these methods in the end if the social benefits in terms of environmental excellence in the space created in the mental health can be considered in terms of living standards in the education space as a base value of human behavior, body and sense the major indicators in the field of mental health in social psychology and human environment as opposed to the assessment that the mental health of the community compared with other communities or other time.

In addition to the sense of space in the mind and in the biological, interactive relationship with memory and location. If you need space to meet the physical characteristics of the body to be removable, but memory out of place; the existence and identity of the person in his mind and he goes anywhere. The memory of that part of the mental attitude of the environment in the form of inters subjective and there is such a space within -time biological self. Its origins in the framework of collective experience, has a special and unique color has become. There is motive enough to mention it. In the period of the contract - conceptual ideas, iconic paradigm of thought during his life meaning and at other times are impressive biological memory. According to the meaning of "Virten", "Abrukramby", "Schultz", "Relph", and "Heidegger" manifested in the following conceptual model.

In Figure 4 on criteria that include changes in biological evolution and that the criteria are based on contrasting or balancing individual and inter subjectivity paradigm of space has been converted in biology. The model in Figure 4 is based on three principles "Ralph", body, Activity (EPA), meaning (identity) which created the space to be in a constant process of course, but the mind and vice versa to create a paradigm of space - time show given.

\section{RESEARCH METHODOLOGY}

Methodology This article is based on qualitative research method with reverse half-structured questionnaire on content analysis of relevant literature on the relationship between evaluation factors, calendar and check their perception of space, was selected .Data collected in the form of words weight are introduced in the conceptual model and through encoding classified and analyzed. In order to achieve intellectual perspectives, sample population into two groups of professors with the pen tool of Tehran University of Fine Arts and the Shahid Beheshti University and new masters of Islamic Azad University professors usually older divided by means of a computer with the pen tool and experience in the exploration of space on the biological aspects of space due to their biological background and experience covered novice teachers more involved in the space of spontaneous, subjective, formal events arising from computer tools and computer processor from the brain Bio-human applications 
in space means less attention has been paid to the body space. Overall, the 47 , according to busy professionals and their training, they have little to work with and try to analyze and compare the two groups. Many ideas were dispersed in comments that were trying to remove the points of convergence with the least amount of votes given and categorize terms of the conceptual model derived from interviews and questionnaires were adapted library studies. The questionnaire was developed in an attempt to master the different aspects of shared meanings in the mind space of the body (Murphy) to the space environment in line with the perception of existence as the ultimate cause of polarized space and attention, or lack of the time factor and the recognition of evaluation criterions space, there was a convergence understand the concepts used. The results of those concepts in the following table are sent.

\begin{tabular}{|c|c|c|}
\hline Total & $\begin{array}{l}\text { New } \\
\text { Professors }\end{array}$ & $\begin{array}{l}\text { Experienced } \\
\text { Professors }\end{array}$ \\
\hline$\% 72$ & $73 \%$ & $29 \%$ \\
\hline$\% 63$ & $53 \%$ & $82 \%$ \\
\hline$\% 36$ & $82 \%$ & $17 \%$ \\
\hline$\% 04$. & $\% 06$. & - \\
\hline$\% 23$ & $\% 2$ & $\% 29$ \\
\hline$\% 68$ & $\% 73$ & $\% 58$ \\
\hline$\% 34$ & $\% 23$ & $\% 52$ \\
\hline$\% 44$ & $\% 26$ & $\% 76$ \\
\hline$\% 34$ & $\% 23$ & $\% 52$ \\
\hline$\% 14$ & $\% 13$ & $\% 17$ \\
\hline$\% 9$ & $\% 7$ & $\% 12$ \\
\hline$\% 91$ & $\% 93$ & $\% 88$ \\
\hline$\% 23$ & $\% 36$ & - \\
\hline
\end{tabular}

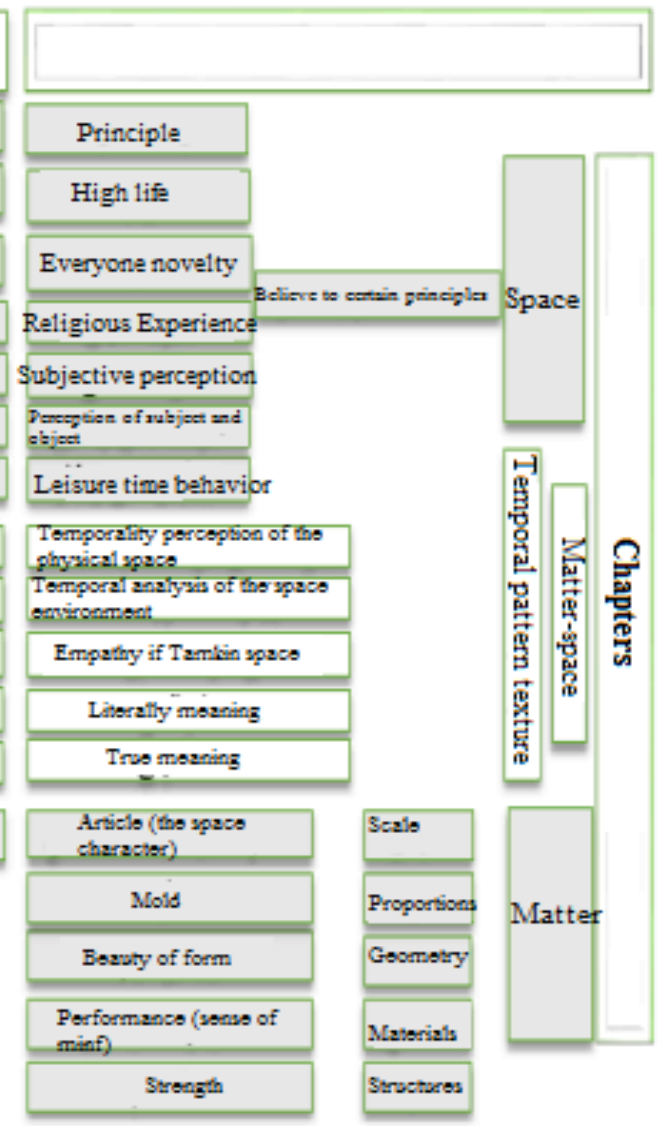

Figure 5. Chart Analysis of the results of the interviews separately contact groups

The perception of a paradigm temporality space, human perception depends on his attitude consistent with the time pattern of living - space is. In this diagram, the more principles-based body material properties, the principles of the semantic space of patterns and principles of proven biological activity and biological behavior in space -time questioned and evaluated.

\section{ANALYSIS OF RESULTS}

In order to analyze the results of the upcoming study, the following criteria as independent variables to define the space created due to the characteristics of the environment as a dependent variable in the analysis before was:

- Different levels of perception space as the essence of architecture.

- Criteria evaluation space.

- Degree of human solidarity and a sense of place space commitment. 
- Creativity and its role in the creation of living (sublime creation, innovation).

The architecture of the participating teachers and $57 \%$ of its characteristics and properties of space separated from the space considered. Among the $70 \%$ of teachers trained to meet the common characteristics associated with space and have enumerated, but the new masters to separate $73 \%$ space and have enumerated above matter. Meanwhile, $76 \%$ of newly qualified teachers together with commitment and attention to architectural space and its properties in the current training is considered poor have. Meanwhile subjective faculty to focus more on the body by means of computers and space form derived from the company of female to all biological identity. The distinction between perception epistemological, ontological $234 \%$ of the audience's understanding of space based on empirical perceptions and mental attitude and $68 \%$ to $23 \%$ based on perceptual space and through presence known.

Among professors to $70 \%$ space specific time has come for the live audience and on temporality as the perception of space and creation focused on evolutionary time.

$51 \%$ of the total population body characteristics and form of the properties and behavior of living space and has meaning derived from the properties of known space. Among the properties of matter and space at the same time professors and $60 \%$ effective in identifying known space. While $88 \%$ qualified teachers has proven principles related to their space. But these principles without a material component with the lowest value are considered. While $6 \%$ of new teachers the sense of neighborliness synchronization of dual material - space endorsed. According to the results of the analysis can be interrelations between different criteria such as subjective and objective space, adhering to the principles fixed in time, measures measurement space, the environmental benefits and levels of human presence in space in the form of a matrix such that the relationship between the aforementioned criteria presented below.

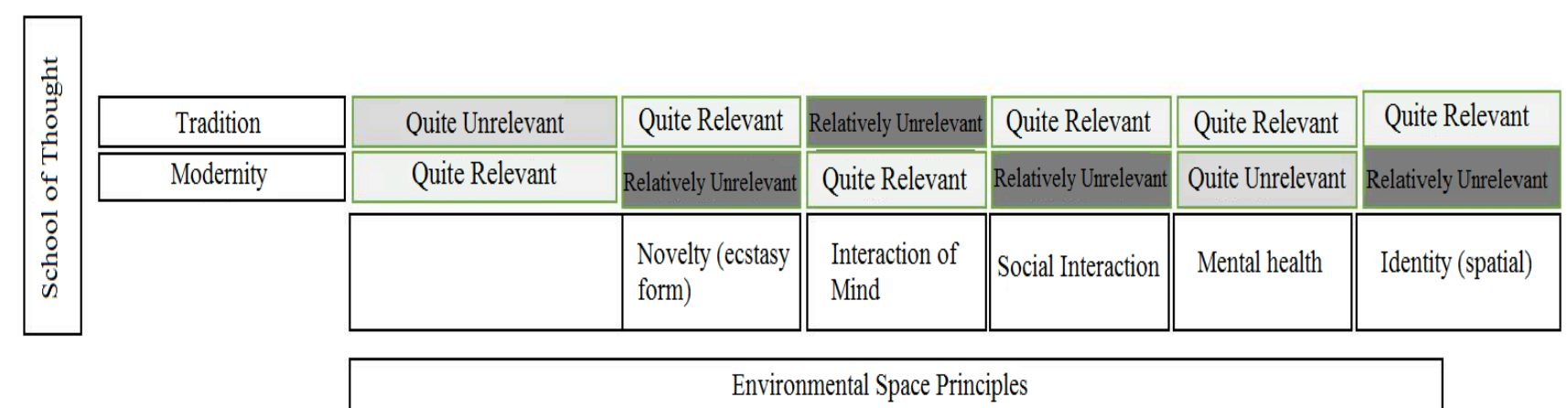

Figure 6. Analysis results of the questionnaire, measures of high school and joy out of life

As Figure 6 Based happens, the results of opinion surveys suggest teachers' present invention the speed of change and modernity born thinking this is one of the criteria used in education is always a commendable and that the creativity, by no means the Beauty comes from a great friendly atmosphere, but the novelty of modernity. As Seyed Hossein Nasr went on to speak to the beauty and creativity in the arts is that people understand the world. In fact, the contrast subject and object in the perception of space architecture of the past in the majority of the a body of objective-subjective and subjective accepted the present architecture facing today's students, particularly given the tools to create mental space to the distant past of human perception works and nearly infallible knowledge of computer, at the same time and the it's about creating a space of attention to the tangible life and graduated from it are known.

\section{CONCLUSION}

The perception leads to the creation of architectural space in the core education of architecture; space, subjective visualization is not enough. Must understand the meaning of living space, experience and criticized, that only the presence of bio-architecture comes during the 
creative process. The presence of bio-architect and creator as organizing the educational process in the past, Iran has manifested novice, beginner and progress hierarchy makers to and Sheikh and the promise of Creation in the soil environment to eat, to come and creating a single space in body and form (beautiful statue) was not expressed, but the biological characteristics of space - time evolution And finally social benefits include increased mental health of humans in space environment were the first to benefit people living creator of space, was an architect. Like any medication before the patient's medical self-test.

As a result, the deficit in the current situation of research on architectural education endorses the architect subjectivist today as the educational process in the studio, on the dictates of their computer, without the presence of life, the essence of and mental space to think. Ultimately, , satisfy the polymorphic figure of body space; only with human visual perception and remove the other senses meets the human perception of space and without regard to the identity and sense of place comes from living. "Place" the ultimate goal of the architect of space, without the presence of human life meaningless and merely meet the physical needs of the human body is in the form. Polaris space means his human identity, what we call places linked. However, the "man" as his name comes of "manmade" but "forgetful" Sometimes, however, fond of He his exile, the land will be forgotten qualities of heaven and eternal truth has not driven the creation of space moment of sublime moments of remembering memories.

In the past, what creating space architecture to create a space novice in the reform process has been taught by great friendly space? The missing link that the quality of human life in space architecture constantly reviewed and improved by the presence and comparable data. In this paper, the principles of human creativity and innovation, increasing knowledge also emphasized that most of the population have not been seriously misunderstood standard, but great creativity in the environment, combined with friendly and emphasized the use of space and architectural space quantitative, numerical, architect architecture with baking space should be separated from human life and should the term "construction" was satisfied. What color and the eternal memory of space in it.Offering short courses in the sociology and psychology and environmental behavior without tangible arc

hitect person cannot represent the totality of funds space; what Norberg-Schultz stressed, is, is. Check the meaning of life without tangible and biological architecture of like the elephant in the dark is what the body It was behavior that creates a space and understand that architecture is not the body to be given only in the form of training, but space - time biological identity of a space leads to the creation of space to understand and criticism of the new previous space by human senses can take place only in the form of presence.

\section{FOOTNOTES}

1. The user architecture- first exposure architectural aspects of life and scale bio Bio actual body space.

2- "Existentialism" the free encyclopedia school that philosophical thinking begins with the human issue, not just a matter of thinking. In existentialism, the beginning of a person's attitude to life.

3- "Temporal" is a term that Heidegger it on the Norberg-Schultz temporality of perception and interpretation of evolutionary time in connection with human life in the space -time.

\section{Edmund Husserl}

5 Martin Heidegger-

6 Rene Descartes

7- David Hume

8 Immanuel Kant

9- Epistemology, knowledge or epistemology of the human perception of the world is concerned.

10- Oncology, ontology, man as being involved in the counting and the way perceptual-ontological being investigated.

11. In view of Heidegger emphasizes that openness and Fatah (dasain) or living space is dependent on the historicity of human understanding. 
12. Platonic definition, space as well as a fixed universe of Indestructible sees that there whatever lies within this space. Aristotle defined space as «topos» notes or place and become part of a more general space knows that it limits the volume range that corresponds to it in its place.

13- Integrity, integrity, relative to the total component

14 morph Shapeless without the addition of a unique property space In order to become a place

15. According to Amos Rapaport housing in anthropology, the term " space "," Inside "and" mother "in the same way primitive tribes' pronunciation.

16. According to the sense of individual creativity and rationality based on material and rerouting or other words of "wisdom-oriented reasoning" (rational). The philosophers of the mind, one reason the argument that minor reason or thrift-minded, calculating, pluralist, based on the breath and the mind (intellect) that holistic wisdom and unity-oriented. (Schwann, 1986).

17. The lack of originality, innovation-based emotional sentimentality means casting and exaggerated sentimentality (Gannon, 2008, 92).

18- Pragmatism that focuses on education rather than on time spent training

\section{REFERENCES}

1. Ardalan, Nader; and, Bakhtiyar Laleh. (2001). Sense of unity: the mystical tradition in Iranian architecture. (Hamid Shahrokh, tranlator). Tehran: Khak publication.

2. Akrami, Gholamreza. (2003). Architecture definition, the first step is education. Journal Honarhaye Ziba. 16, 33-48.

3. Bergson, Henri Louis. (1997). Creative Evolution. (Ali Qoli Bayani, Translator). The second edition, Tehran: Office of Islamic culture.

4. Partoei, Parvin (2008). Phenomenology place. Tehran: Publication Farhangestan Honar.

5. Hojat Eisa. (2012). Tradition and innovation in architectural education. Third Edition, Tehran: Publication of Tehran University.

6. Hojat, Mahdi. (1998). Perception of space. Journal porch, 1, 17-27.

7. Raeis Dana, Farrokh Legha. (1991). A description of how to evaluate the total experimental design. Journal of Education, 41, 96-130.

8. Zouy, Browno (2009). How we look at architecture. (FArideh Garman, Translator). Printing, Tehran: Publication Shahidi.

9. Schwann, Fritroof; and Houston, Smith. (2007). Transcendent unity of religions, (translation Gholamreza Dadkhah). Journal of Information wisdom, 15, 36.

10. Schultz, Norberg. (2001). new concept of architecture, (Nayer Tahuri: Translator). Quarterly architect, 14.

11. Schultz, Norberg. (2002). Architecture, attendance, time and location. (Reza Seyyed Ahmadi, Translator). Tehran: Lotus Publishing.

12. Zamiran, Mohammad. (2011). Foucault's critique of modern reason. Journal of wisdom and knowledge. 69, 51-56.

13. Falamaki, Mohammad Mansur. (2011). the roots and theoretical trends in architecture. Fourth Edition, Tehran: publishing space.

14. Golabchi, M.; and Alaghemandan, M. (2010). Paul of Iran and the world: architecture, technology, and beauty. Printing, Tehran: Tehran University.

15. Guenon, Rene. (2008). the crisis of the modern world. (Hassan Azizi, Translator). Printing, Tehran: Publishing Hekmat.

16. Moein, M (1976). Persian culture given six volumes. (Dr. Jafar Shahidi, editor). Tehran: Publication of Amir Kabir.

17. Mrriyahi, Saeed. (2006). Arbitration architectural design and its consequences. Journal of Saffeh 42, 86-96.

18. Nasr, Seyed Hossein. (2000). Progress towards peace and truth. Tehran: Publication Pol Riruzeh.

19. Heidegger, Martin. (2007). Being and Time. (Siyvash Jamadi, Translator). Printing, Tehran: Publication Ghoghnus.

20. Abercrombie, M. I. J. (1969). The Anatomy of judgment. , Harmon worth, Penguin, UK.

21. Boyer, C. (1998). The City of Collective Memory, Its Historical Imaginary and Architectural Entertainments. Ma, MIT Press. 
22. Kurt, S. (2009). An Annalistic Style on the Traditional Studio Environmental and the Use of Constructivists Studio in the Architectural Design Education. Procedia Social and Behavioral Science Journal. 1, 1, 401-408.

23. Markus, J. (2003). Student Assessment and Evaluation In Studio Art, Research In Ontario Second School. Vol. 8, Canada.

24. Schulz, CN (1975). Meaning in Western Architecture. New York: Rizzoli.

25. Ralph, E. (1976). Place and Placelessness. Pion, London.

26. Worthen, BR, \& Sanders, JK (1987). Alternative Approach and Practical Guideline, New York: Longman.

INTERNET RESOURCES:

http: //www.wikipedia.fa.m.org,2013 (date 2013) 